\title{
Kapasitas Komunitas Lokal dalam Pengembangan Pariwisata Pedesaan
}

\author{
Oleh : Okta Hadi Nurcahyono ${ }^{1}$
}

\begin{abstract}
Abstrak
Artikel ini adalah hasil dari penelitian lapangan mengenai komunitas desa wisata yang terbentuk atas dasar strategi pembangunan kepariwisataan Indonesia. Salah satu startegi pembangunan pariwisata Indonesia adalah pariwisata berbasis komunitas. DI Yogyakarta adalah salah satu provinsi yang berhasil mengembangkan pariwisata berbasis kominitas. Penelitian ini mengambil sampel di salah satu desa wisata yang dikembangkan di Kabupaten Sleman, DI Yogyakarta. Penelitian ini adalah penelitian kualitatif dengan pendekatan penelitian studi kasus. Teknik sampling yang digunakan adalah snowball sampling. Analisis data yang digunakan dalam penelitian ini menggunakan model analisis interaktif dari Miles dan Hubberman. Desa wisata adalah satu perwujudan dari pariwisata berbasis komunitas. Proses terbentukannya ada yang bersifat bottom up (inisiatif dan partisipatif masyarakat) dan top down (dibentuk oleh pemerintah). Komunitas Desa Wisata Grogol sebagai sebuah komunitas yang terbentuk dari strategi pengembangan pariwisata berbasis komunitas di pedesaan. Komunitas Desa Wisata Grogol sebagai sebuah komuntas memiliki modal apa yang disebut Chaskin (2001) sebagai kapasitas komunitas. Kapasitas komunitas pada desa wisata ini bermanfaat untuk mengembangkan pariwisata khususnya pariwisata pedesaan di Indonesia.
\end{abstract}

Kata Kunci: Pariwisata Pedesaan, komunitas, kapasitas komunitas

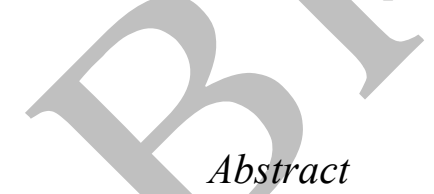

This article is the result of field research on tourism village communities formed on the basis of Indonesia's tourism development strategy. One of Indonesia tourism development strategy is community-based tourism. In Yogyakarta is one of the provinces that successfully develop comminity-based tourism. This study took samples in one of the tourist villages developed in Sleman, Yogyakarta. This research is a qualitative research with case study research approach. The sampling technique used was snowball sampling. Data analysis used in this research use interactive analysis model from Miles and Hubberman. The tourist village is an embodiment of community-based tourism. The establishment process is bottom up (initiative and participative community) and top down (formed by the government). Grogol Village Community Community as a community formed from a community-based tourism development strategy in the countryside. Grogol Village Village Community as a community has what capital is called Chaskin (2001) as community capacity. Community capacity in this tourist village is useful to develop tourism especially rural tourism in Indonesia.

Keyword: village tourism, community, capacity community

\footnotetext{
${ }^{1}$ Staff Pengajar di Program Studi Pendidikan Sosiologi-Antropologi FKIP Universitas Sebelas Maret
} 


\section{A. Latar Belakang}

Undang-undang Nomor 25 tahun 2000 Tentang Perencanaan Nasional Pariwisata dinyatakan bahwa strategi pembangunan kepariwisataan Indonesia adalah peningkatan daya saing destinasi pariwisata; pengembangan pariwisata berbasis komunitas; pemasaran terpadu baik pasar di dalam negeri maupun di luar negeri; peningkatan kualitas pelayanan pariwisata; pengembangan infrastruktur terutama kasebilitas; pengembangan sumberdaya manusia (standarisasi, akreditasi dan sertifikasi) dan sinergi multi-stake holder sejak perencanaan sampai pada pelaksanaan (Ministry of Culture and Tourism Republic Indonesia, 2003; Suwasono, 2003; Demartoto, 2015). Salah satu strategi pariwisata yang sudah ditetapkan oleh pemerintah seperti yang tercantum dalam Undang-undang Nomor 25 tahun 2000 Tentang Perencanaan Nasional Pariwisata adalah pengembangan pariwista berbasis komunitas local (Community Based Tourism).

Esensi dari Pariwisata pariwista berbasis komunitas local (Community Based Tourism) adalah menempatkan masyarakat local sebagai subjek sekaligus obyek pembangunan. Menurut Demartoto (2015) Kebijakan pengembangan pariwisata berbasis komunitas telah teruji keefektifannya dibandingakan dengan model pariwisata yang lain seperti pariwisata masal. Dari berbagai penelitian di dunia mengenai pengembagan pariwisata berbasis komunitas memberikan dampak postif bagi masyarakat local khususnya dalam peningkatan ekonomi, social dan budaya masyrakat. Pada hakekatnya menurut Pendit (1990) ada empat bidang pokok yang dipengaruhi oleh usaha pengembangan pariwisata, yaitu ekonomi, sosial, budaya, dan lingkungan hidup. Dampak positif yang menguntungkan dalam bidang ekonomi yaitu bahwa kegiatan pariwisata mendatangkan pendapatan devisa negara dan terciptanya kesempatan kerja, serta adanya kemungkinan bagi masyarakat lokal di daerah tujuan wisata untuk meningkatkan pendapatan dan standar hidup mereka. Dampak positif yang lain adalah perkembangan atau kemajuan kebudayaan, terutama pada unsur budaya teknologi dan sistem pengetahuan yang maju. Dampak negatif dari pengembangan pariwisata tampak menonjol pada bidang sosial, yaitu pada gaya hidup masyarakat di daerah tujuan wisata. Gaya hidup ini meliputi perubahan sikap, tingkah laku, dan perilaku karena kontak langsung dengan para wisatawan yang berasal dari budaya berbeda. 
Berbagai penelitian baik dalam maupun luar negeri banyak sudah yang menunjukan dampak dari kegiatan pariwisata khusunya dari segi ekonomi masyarakat, Seperti dalam penelitian yang dilakukan oleh: Aradhyula and Tronstad (2003), IUOTO (1975), Rodernburg (1980), Udayana University (1975), Walope (2000) dan Wilson (2008), Ahimsa (2012), dan sebagainya. Tetapi sedikit sekali yang kemudian meneliti dampak budaya dari kegiatan ekonomi kepariwisataan, khusunya diwilayah pariwisata pedesaan. Disinilah tugas para antropolog dalam mengakji fenomena itu, meskipun para antropolog sudah banyak mengakajinya misalnya studi-sudi yang dilakukan oleh Cohen (1979a,b), de Kadt (1979), Farrell (1977a), Finney dan Watson (1975), Knox dan Suggs (1979), Smith 1977a,1978a,b,1980a). Tetapi jarang sekali penelitian yang membahas bagaimana porses didalam pariwista yang berbasis komunitas. Apa lagi sektor pariwisata pedesaan ini masih kurang mendapat perhatian dari tangan-tangan peneliti sosial budaya, terlebih beberapa dekade ini dikenal istilah "desa wisata".

Fenomena "Desa Wisata" yang menghisasi dunia pariwisata, khususnya pariwisata pedesaan di Yogyakarta selama dua dekade terakhir ini. Meskipun secara konseptual "Desa wisata" masih menjadi sebuah krisis dan perdebatan dikalangan para akademisi, Tetapi hadirnya desa wisata mampu menjadi sebuah gejala sosial baru yang mengubah tatanan sosial yang ada di pedesaan. Dimana desa-desa yang memiliki potensi wisata kemudian disulap menjadi "desa wisata" oleh Pemerintah Daerah, baik Provinsi maupun Pemerintah Kabupaten Sleman, yang tujuan utama adanya desa wisata ini adalah untuk mensejahterakan masyarakat lokal khusunya dalam hal ekonomi. Motif ekonomi inilah kemudian menghasilkan proses perubahan sosial dan budaya yang juga tidak jarang mengahasilkan masalah sosial baru, bahkan friksi dalam masyarakat. Untuk itu diperlukan kajian serius dan mendalam mengenai proses dinamika kebudayaan yang terjadi dalam proses terbentuknya komunitas.

Di Yogyakarta terdapat beberapa "Desa Wisata" yang terbagi ke dalam tiga kategori besar yaitu desa wisata mandiri, desa wisata berkembang, dan desa wisata tumbuh. Kabupaten Sleman ini menurut wawancara peneliti dengan salah seorang Staf di Dinas Pariwisata Kabupaten Sleman, terdapat 38 desa wisata yang terdiri dari 12 desa wisata tumbuh, 13 desa wisata bekembang, dan 13 desa wisata yang tergolong kedalam kategori desa wisata mandiri. Dari 38 desa wisata ini menurut Firdaus (Ahimsa: 2011) terbagi lagi menjadi enam segmen desa wisata yaitu (1) desa 
wisata budaya, (2) desa wisata pertanian, (3) desa wisata kerajinan, (4) desa wisata fauna, (5) desa wisata merapi, dan (6) desa wisata pendidikan. Penelitian ini dilakukan di salah salah satu dukuh di Desa Margodadi, Kecamatan Sayegan, Kabupaten Sleman yang juga merupakan salah satu desa wisata, yaitu Dukuh Grogol yang sejak 2001 ditetapkan dalam kategori “desa wisata budaya”. Desa Wisata Budaya Grogol ini digolongkan menjadi desa wisata tumbuh dari 2001, dan baru menjadi desa wisata berkembang setelah 2010.

Penelitian ini menjadi menarik karena melihat bagaimana proses terbentuknya sebuah komunitas akibat adanya pengembangan pariwisata di pedesaan. Proses berkomunitas ini menjadi menarik, melihat respon anggota masyarakat terhadap komunitas yang terbentuk. Selain itu, penelitian ini mengidentifikasi kapasitas komunitas didalam satu komunitas desa wisata. Dengan mengdentifikasi kapasitas komunitas diharpakan dapat mngetahui bagaiman kapasitas sebuah komunitas dalam mengembangkan periwisata khususnya pariwisata pedesaan.

\section{Kapasitas Komunitas dalam Pengembangan Pariwisata}

Tema pariwisata sudah menjadi kajian yang menarik di kalangan ilmuwan antropologi, sejak 1970-an. Bagi para antropolog fenomena pariwisata dapat menjadi jalan masuk dalam mengkaji isu-isu seperti: ekonomi politik, perubahan sosial dan pembangunan, pengelolaan sumberdaya alam, identitas budaya dan ekspresi. Dengan prekspektif holistiknya ilmu antropologi menjadi penting dalam mengeksplorasi fenomena pariwisata yang ada. Secara konseptual Stronza (2001) membagi kajian antropologi dalam tema pariwisata menjadi dua bagian yaitu memahami asal-usul pariwisata dan salah satu yang bertujuan untuk menganalisis dampak pariwisata. Kedua fokus kajian antropologi dalam memahami tema wisata ini berbeda, disatu sisi studi tentang asal-usul pariwisata yang cenderung fokus pada wisatawan dan penelitian diarahkan pada dampak pariwisata cenderung menganalisis hanya penduduk setempat. Pada penelitaian ini peneliti cenderung membawa tema pariwista cenderung menganalisis dampak budaya yang ditimbulkanya dari proses pariwisata pedesaan.

Desa wisata adalah suatu bentuk terminologi yang menggambarkan proses pariwisata yang berbasis pada pedesaan. Terlepas dari kontroversi konsep desa wisata ini, Menurut Ahimsa-Putra (2000) pengertian desa wisata mengarah kepada suatu bentuk kawasan pemukiman yang terdapat pada daerah pedesaan, baik secara sengaja 
atau tidak sengaja, telah menjadi sebuah kawasan yang menjadi tujuan kunjungan wisatawan karena memiliki daya tarik atau obyek wisata, dan desa wisata ini wisatawan dapat melakukan kegiatan menginap. Kata menginap pada bagian akhir pada bagian akhir pengertian itu menjadi sangat penting, sehingga terkait erat dengan keberadaan home stay (penginapan). Karena hibitus masyarakat desa, kekayaan alam, sosial budaya menjadi atraksi tersendiri bagi wisatawan. Daya tarik inilah yang menggiring para wisatawan untuk mencoba pariwisata berbasis pedesaan, sebagai alternatif wisata.

Banyak kajian mengenai pariwisata yang berbasis komunitas atau dikenal dengan istilah Community-based tourism (CBT), khususnya di pedesaan baik di dalam maupun di luar negeri. Kajian Wearing dan Mc Donald (dalam Demartoto, 2015) mengenai obyek wisata pedesaan di Papua New Guenia, yang pengelolaannya dikelola oleh komunitas local dapat memberikan manfaat postif dan kunjungan wisatawan dapat membuka komunikasi masyrakat khususnya masyarakat yang terisolir. Kajian Cohen (2004) di Oxaca, Mexico, mengenai usaha tekstil yang digeluti oleh orang India, berperngaruh terhadap industry pariwisata masyarakat dan berdampak positif pada tingkat social ekonomi masyarakat dibandingkan dengan wilayah lain. Penelitian Lesegos. Sebele (2010) menunjukan bagaimana Community Based Tourim (CBT) di komunitas Botswana menjadi win-win solution dalam menjaga konservasi sumber daya alam dan peningkatan penghidupan masyarakat local.

Pengembangan pariwisata pedesaan berbasis pada komunitas tidak semuanya dapat berhasil, tantangan terbesar adalah tingkat partisipasi masyarakat. Penelitian Hui Wang dkk (2010) menunjukan rendahnya tingkat partisipasi masyarakat dan implikasinya terhadap pengembangan pariwisata di masa depan dibahas dengan mengacu pada pengembangan pariwisata masa depan di Cagar Alam Kanas, China. Tantangan lain mislanya rendahnya partisipasi perempuan dalam pariwisata berbasis komunitas yang ditunjukan oleh penelitian Dermatoto (2015), penelitian yang dilakuakn di Desa Samiran, Kecamatan Selo, Boyolali memperlihatkan bagaimana menempatkan perempuan sebagai obyek bukan subyek dalam pembangunan pariwisata pedesaan. Selain itu CBT juga tidak lepas dari konflik kepentingan antar pihak professional (misalnya pemandu wisata professional) dengan penduduk setempat atau komunitas lokal seperti dalam penelitian Salazar (2011). 
Pada dasarnya definisi kapasitas komunitas adalah gabungan dari kata komunitas (community) dan kapasitas (capacity). Komunitas adalah anggota masyarakat yang terlibat dalam system memiliki sense dan memahami hubungan dan areal kepentingan bersama. Seringkali didasari oleh homogenitas (kesamaan atribut yang dimiliki oleh anggotanya), tetapi yang lebih penting lagi adalah communality (kesetaraan) yaitu suatu kondisi dimana terdapat hal yang dibagi antara anggotanya, tetapi tidak selalu berasal dari atribut yang dimiliki, melainkan berdasarkan pada motivasi, tujuan, keinginan, hubungan darah, dan mutuality (kebersamaan).

Komunitas timbul karena adanya kesamaan dalam geografis masyarakat, seperti lingkungan perumahan, kesamaan sosial seperti etnis tertentu, pendidikan, umur, dan kesamaan interest (minat). Komponen dari communities dimulai dari level terendah di masyarakat yaitu individu, informal group, organisasi hingga level lainnya yang lebih tinggi. Komunitas bersifat dinamis yaitu dapat berubah sesuai dengan waktu dan tempat dimana kemunitas itu berada. Contoh komunitas di Indonesia adalah RT/RW, berdasarkan pekerjaan, kelompok adat, perdesaan, serta keagamaan. Komunitas juga dapat memiliki kombinasi dalam kesamaannya, misalnya kesamaan geografis dan sosial seperti pada kota-kota tua yang berisikan para imigran dari suatu negara (Golab, 1982; Masey, 1985; Portes and Mining, 1986; Chaskin, 2001 dalam Imran 2012).

Burke dalam Imran (2012), menjelaskan bahwa dalam kamus perencanaan sosial yang bersifat sukarela, dibuat perbedaan antara community 'fungsional' dengan community 'geografis'. Community geografis, yang secara tidak langsung diartikan oleh istilah itu sendiri, didefinisikan oleh batas geografis seperti neighborhood, kota, wilayah metropolitan, propinsi, dan sebagainya. Di lain pihak, sebuah community fungsional terdiri dari individu maupun kelompok yang memiliki kepentingan yang sama. Capacity terdiri dari dua hal, yaitu containing dan ability, baik dari pemikiran maupun tindakan. Secara umum, kapasitas komunitas merupakan sesuatu yang dapat membuat suatu komunitas "bekerja" dan dapat membuat suatu komunitas yang berfungsi dengan baik akan bekerja sesuai dengan fungsinya tersebut.

Pada tingkatan yang dasar, kemampuan individu yang membentuk kapasitas komunitas terkandung di dalam komunitas tersebut, tetapi mereka juga harus menciptakan hubungan kerjasama terhadap sistem yang lebih besar dimana komunitas tersebut ikut berperan. Chaskin (2001) berpendapat bahwa kapasitas komunitas merupakan interaksi dari modal manusia, sumberdaya organisasi, dan modal sosial 
yang terdapat di dalam komunitas yang dapat berpengaruh dalam pemecahan permasalahan kolektif dan meningkatkan serta menjaga kesejahteraan komunitas. Kapasitas komunitas dapat bekerja di dalam proses sosial secara informal maupun usaha yang terorganisir baik oleh individu, organisasi, dan jejaring sosial yang terdapat di dalam dan di antara komunitas tersebut serta pada sistem yang lebih luas dimana komunitas tersebut menjadi bagiannya. Beberapa definisi dari pembangunan komunitas fokus pada cadangan lokal komitmen, keterampilan, sumber daya, dan kemampuan dalam memecahkan masalah, seringkali juga dihubungkan baik dengan program maupun lembaga tertentu (Mayer, 1994; Aspen Institute, 1996 dalam Chaskin 2001).

Pendekatan lain menekankan pada partisipasi dari anggota individu dalam komunitas dalam proses membangun hubungan, perencanaan komunitas, pengambilan keputusan, dan tindakan (Gittel, Newman, Ortega, 1995 dalam Chaskin 2001). Dari berbagai dimensi, kapasitas komunitas memiliki perbedaan dalam berbagai pendekatan. Beberapa fokus terutama pada organisasi dan beberapa pada individu; beberapa fokus pada hubungan afektivitas dan shared values, sedangkan yang lain memberikan prioritas terhadap partisipasi dan keterlibatan. Akan tetapi, beberapa definisi kapasitas komunitas tersebut mencakup beberapa faktor, yaitu: keberadaan sumber daya, memiliki range dari kemampuan individu hingga kekuatan organisasi untuk mengakses modal finansial; jaringan hubungan, jaringan hubungan terkadang terkonsentrasi pada lingkup afektif, di saat yang lain terkonsentrasi pada lingkup instrumental; kepemimpinan, memiliki banyak definisi, salah satunya adalah kemampuan untuk mengelola sumber daya alam dan juga manusia secara dewasa dan bertanggung jawab; dukungan untuk pergerakan (mobilitas), adanya partisipasi dari anggota komunitas dalam tindakan kolektif dan pemecahan permasalahan.

Pengembangan kapasitas komunitas fokus pada beberapa kombinasi dari empat strategi utama, yaitu (Chaskin, 2001): a. Leadership Development, yang fokus kepada keahlian, komitment, keterlibatan, dan keefektivan individu dalam proses pengembangan komunitas. b. Organizational Development, termasuk membentuk organisasi baru atau memperkuat yang sudah ada sehingga mereka dapat bekerja lebih baik atau mengambil peran baru. c. Community Organizing, memiliki target pengumpulan aspek-aspek dari fungsi komunitas dan memobilisasi stakeholder individu untuk menjadi kolektif pada akhirnya. d. Interorganizational Collaboration, 
membangun infrastruktur organisasi komunitas meliputi pengembangan hubungan dan kerjasama kolaboratif dalam level organisasi.

\section{Metode Penelitian}

Penelitian ini adalah penelitian kualitatif dengan pendekatan penelitian studi kasus (Yin, 2005; Denzin dan Lincoln, 2011). Studi kasus analisa situasional adalah penelitian yang berfokus kepada kehidupan sosial dinamis yang mengalami perubahan sebagai bagian dari terjadinya peristiwa social tau fenomena social. Penelitian ini dilakukan di Desa Margodadi, Kecamatan Sayegan Kabupaten, Sleman Yogyakarta. Sampel penelitian ini adalah para anggota komunitas desa "desa wisata". Teknik sampling yang digunakan adalah snowball sampling. Data yang terkumpul terdiri atas data primer dan data skunder. Penggalian data primer dengan teknik wawancara mendalam, partisipasi observasi, dan observasi, sedangkan data skunder diperoleh data dari desa, dan dinas pariwisata. Pada penelitian ini proses analisis data menggunakan model analisis interaktif dari Miles dan Hubberman (Denzin dan Lincoln, 2011) meliputi tahap reduksi datâ, penyajian data dan penarikan kesimpulan.

\section{Hasil Penelitian}

\section{Grogol: antara Padukuhan dan Komunitas}

Dukuh Grogol terdapat di wilayah administratif Desa Margodadi, Kecamatan Sayegan, Kabupaten Sleman, Daerah Istimewa Yogyakarta. Desa Margodadi terletak di sebelah barat daya dari ibukota atau pusat administrasi Kabupaten Sleman dan barat laut dari pusat administrasi ibu kota provinsi DI Yogyakarta. Tepatnya secara astronomis letak Desa Margodadi berada di 7.72119` LS dan 110.30841`BT. Akses jalan dari danmenuju ke Dukuh Grogol atau Desa Margodadi ini sudah beraspal, dengan klasifikasi jalan yang terdiridari, jalan nasional, jalan provinsi maupun jalan kabupaten. Sementara untuk kendaraan yang dapat digunakan adalah kendaraan pribadi seperti motor maupun mobil, sedangkan untuk kendaraan umum seperti bus, atau angkot dari Kota Yogyakarta hanya sampai di Kecamatan Godean dan dilanjutkan ojek atau tranportasi pribadi lainya. Waktu tempuh dari pusat Kota Yogyakarta ke Dukuh Margodadi cukup bervariatif tergantung pada kondisi jalan, tetapi rata-rata waktu tempuh dari pusat Kota Yogyakarta 30 menit.

Dukuh Grogol, Desa Margodadi ini tergolong dalam kategori dataran rendah dengan kontur tanah yang relatif datar, meskipun ada beberapa bukit yang terdapat 
disana. Sementara itu Desa Margodadi ini berada diketinggian 160m dari permukaan laut. Dengan suhu yang relatif bersahabat, pada saat peneliti berada disana suhu pada siang hari $30^{\circ}$ dan malam hari mencapai $22^{\circ}$, karena pada saat itu musim kemarau. Sementara suhu rata-rata $27^{0}$ menurut data kependudukan desa. Sementara itu curah hujannya mencapai $2.235 \mathrm{~mm}$. Luas wilayah Desa Margodadi 611.0000 ha, yang terdiri dari luas lahan pekarangan 164.4950 ha, persawahan 377.3655 ha dan lain-lain 68.1505 ha.Semantara itu luas wilayah Dukuh Grogol mencapai 35.2770 ha, yang terdiri dari lahan basah dan kering. Luas tanah untuk pertanian 15.4202 ha dan 16.6518 ha untuk lahan pekarangan. Jika dilihat dari data tersebut luas lahan kering atau lahan pekarangan lebih luas jika dibandingkan dengan luas lahan basah atau pertanian. Selain memiliki panorama area persawahan yang di hiasi bukit-bukit yang indah, Grogol juga memiliki beberapa sumber mata air. Sumber mata air ini tidak ini terus mengalirkan air meskipun pada musim kering. Di Grogol sumber mata air ini biasa dikenal dengan istilah " $t u k$ " yang kemudian mengalir melalui pancuranpancuran atau langsung masuk ke sendang. Rata-rata tiap tuk yang ada di Grogol mampu menghasilkan debit air sekitar 40 liter perdetik. Sehingga dapat disimpulkan daerah ini cukup subur untuk sektor pertanian juga cocok untuk usaha perikanan.

Sejarah keberadaan Dukuh Grogol tidak lepas dari foklor Sunan Kalijogo yang sedang melakukan syiar Islam dan singgah di Dukuh Grogol. Meskipun tidak ada suatu penjelasan tertulis mengenai sejarah awal keberadaan Dukuh Grogol dan kehidupan masyarakatnya. Berdasarkan cerita yang diwariskan secara turun-temurun dikalangan Masyarakat Grogol, keberadaan sudah sedemikian lama. Nama "Grogol" sendiri menurut cerita yang berkembang di masyarakat diambil dari kata grogoli yang berarti jatuh atau rontok, dalam kisah ini kaitannya adalah kisah ketika Sunan Kali Jogo menyisir rambutnya dan memotong kuku. Ketika beristirahat bersama para pengikut atau santrinya Sunan Kalijogo menyisir rambut dan memotong kuku. Kemudian rambut Sunan Kalijogo jatuh atau rontok, disebut dengan istilah masyarakat pada saat itu grogoli. Kemudian istilah itu berulang-ulang diucapkan sehingga akhirnya disebut tempat dimana Sunan Kalijogo singgah dan beristirahat dengan nama "Grogol”. Selain nama foklor yang kemudian berkembang di dukuh Grogol atas dasar kejadian yang dialami oleh Sunan Kali Jogo. Foklor itu antara lain seperti : tidak boleh ada regol di Grogol, tidak boleh menggunakan rumah joglo, tidak 
boleh menam ketan, dan terebih adalah petilasan yang dianggap sakral terlebih ketika ada pasangan setelah menikah harus mengelilingi temapat atau petilasan ini.

Jika dahulu tingkat pendidikan masyarakat masih dikatakan rendah, Grogol pada saat tingkat pendidikan masyarakat sudah cukup menggembirakan. Penduduk yang sudah menamatkan bangku SMA berjumlah 266 yakni 36\% dari keseluruhan penduduk Dukuh Grogol yang berjumlah 732. Kebanyakan dari mereka yang lulus dari bangku Sekolah Menengah Atas ini bekerja di sektor swasta, perusahaan swata atau berwirausaha. Sementara yang sudah menamatkan bangku perguruan tinggi atau universitas berjumlah 81 orang, yakni $11 \%$ dari jumlah penduduk dukuh Grogol. Dari $11 \%$ yang sudah menamatkan pendidikannya sampai jenjang perguruan tinggi.Tingkat pendidikan masyarakat yang cukup tinggi sehingga mempengaruhi mata pencaharian yang dijalankan. Jika dahulu mayoritas warga Dukuh Grogol bekerja sebagai buruh tani dan industri batu bata dan genteng tanah liat. Tapi pada saat ini setelah hadirnya wisata masuk ke Dukuh Grogol lahirlah mata pencaharian baru yaitu sebagai pemandu desa wisata. Dengan hadirnya wisata yang semakin lama semakin berkembang juga berdampak pada ekonomi masyarakat, khususnya yang tergabung dalam komunitas desa wisata.

Komunitas Desa Wisata Grogol ini terbentuk sejak pendirian desa wisata di dukuh Grogol yaitu tahun 2001. Komunitas ini pertama dibentuk atas instruksi dari pemerintah Kabupaten Sleman melalui penggiat seni di Dukuh Grogol yang juga berprosesi sebagai guru kesenian yaitu Bapak Sancoko. Setelah terbentuk tidak ada aktivitas berarti kecuali upacara adat thuk si-bedhuk yang juga sebagai agenda rutin Kabupaten Sleman. Pembentukan awal komunitas ini bersifat instruktif dari atas dalam hal ini pemerintah kepada warganya. Hal ini mengakibatkan kurang terjalinnya sense of belonging para anggota komunitas terhadap komunitasnya, atau dengan kata lain kurangnya sadarnya para anggota komunitas untuk berkomunitas. Selain itu tidak berkembangnya komunitas desa wisata di dukuh grogol karena adanya "penolakan (rejection)" dari orang-orang yang merasa terganggu kepentingannya, seperti para peternak ayam dalam skala besar.

Pada tahun ke-sepuluh para pemuda desa mulai sadar akan pentingnya keberadaan desa wisata di desanya. Pada awalnya yang terkumpul hanya 5 orang kemudian mereka mengajak para pemuda yang lain untuk bergabung dalam komunitas desa wisata. Tidak sedikit diantara pemuda desa yang menolak gabung dalam komunitas desa wisata. Setelah berjalan dengan kurang dari 20 orang akhirnya 
mulailah komunitas ini mendapatkan penghasilan dan nampak hasilnya akhirnya para pemuda yang dulu menolak akhirnya bersedia bergabung dengan komunitas desa wisata.

Meskipun dalam proses komunikasi difusi atau dalam bahasa Rogers disebut “Innovation-Discision Process" kembali menerima penolakan, tetapi dengan potensi dan kekuatan seadanya konsep "desa wisata" dapat berjalan dan berkembang di Dukuh Grogol seperti sekarang. Pada akhir 2014 anggota komunitas ini mencapai 45 orang dan bertambah di tahun 2015 yang lebih dari 50 orang dan sekrang hampi 80 orang baik pemuda, orang tua dan ibu-ibu bergabung dalam komunitas desa wisata. Komunitas ini memiliki kegiatan rutin yakni bersih-bersih fasilitas yang ada di lokasi wisata, menyambut dan mendampingi wisatawan, dan juga pertemuan bulanan yang digilir setiap bulannya. Selain itu komunitas desa wisata grogol juga sesekali dalam satu tahun mengadakan wisata bersama untuk menciptakan solidaritas diantara anggota komunitas, dan tidak lupa mereka meng-update ilmu khusunya ilmu mengenai kepariwisataan baik bagaiman cara menyambut tamu, memandu, sampai bagaimana cara menyediakan hidangan untuk tamu.

\section{Identifikasi Kapasitas Komunitas Desa Wisata Grogol}

Setiap komunitas memiliki modal, guna menunjang kapasitas yang komunitas miliki. Menurut Green dan Haines (2002) dalam Nur Imran (2012) ada enam modal yang dimiliki komunitas. Berikut modal komunitas yang dimiliki oleh Komunitas Desa Wisata Grogol:

a. Modal fisik Modal fisik, Menurut Green dan Haines (2002) dalam Nur Imran (2012) membagi modal fisik ke dalam dua kelompok, yaitu bangunan (building) dan infrastruktur (infrastructure). Pada kasus Komunitas Desa Wisata Budaya di Grogol, modal fisik mulai Nampak ketika tahun 2010, setelah kepengurusan dijalankan oleh para kaum muda. Bangunan yang dimiliki diperoleh komunitas ini dari dana PNPM tahun 2012 dan 2013, serta bantuan dari Dinas Pariwisata Provinsi. Berikut jumlah dana pada tabel 1 yang di dapatkan dalam mengembangkan Desa Wisata Budaya Grogol dan peruntukan dananya:

Tabel 1 Peruntukan dan pemanfaatan Dana PNPM di Grogol 


\begin{tabular}{|c|c|c|c|}
\hline No & Tahun & Jumlah Dana & Pemanfaatan Dana \\
\hline 1 & 2012 & Rp. 75.000.000,- & Membangun kolam renang dan gamelan \\
\hline 2 & 2013 & Rp.100.000.000,- & Mebangun rest area dan beberapa Gazebo \\
\hline
\end{tabular}

Sumber: Wawancara

Dengan adanya dana tersebut, Pada tahun 2012 Desa Wisata mampu membuat Aula atau rest area yang berbentuk rumah panggung dari bambu, dan kolam renang alam, serta melakukan berbagai pelatihan kepada pengelola desa wisata. Sementara infratuktur seperti jalan menuju lokasi desa wisata dibangun secara swasembada masyrakat Dukuh Grogol. Untuk pengaspalan jalan menuju padukuhan ini dikerjakan oleh Pemerintah Daerah pada tahun 2013. Baik modal infrastuktur maupaun bangunan dimiliki oleh komunitas desa wisat Grogol.

b. Modal Finansial Modal finansial, adalah dukungan keuangan yang dimiliki suatu komunitas yang dapat digunakan untuk membiayai proses pembangunan yang diadakan di dalam komunitas tersebut. Modal finansial yang dimiliki ataupun diakses oleh komunitas dapat menentukan kesejahteraan dari komunitas tersebut. Seperti halnya komunitas lain pada awalnya modal finansial Komunitas Desa Wisata Grogol diperoleh dari iuran anggota. Tetapi dengan semakin banyaknya jumlah wisatawan yang hadir di Desa Wisata Grogol, semakin banyak juga modal finansial yang dimiliki oleh komunitas Desa wisata Grogol. Pada tahun 2015 Desa Wisata Grogol memperoleh pendapatan Rp.96.980.000,-, dari wisatawan. Pada saat ini dengan semakin banyaknya jumlah wisatawan pastinya berbanding lurus dengan modal finansial yang dimiliki komunitas. Komunitas ini dapat memberi upah para anggota setiap bertugas mendampingi wisatawan atau memberi pelayanan kepada para wisatawan seperti menyipakan konsumsi, menjadi instruktur outbond, atau membersihkan fasilitas wisata yang dimiliki komunitas.

c. Modal Lingkungan Modal lingkungan adalah potensi yang belum diolah dan mempunyai nilai ekonomi yang tinggi, serta mempunyai nilai yang tinggi dalam upaya pelestarian alam dan juga kenyamanan hidup dari manusia dan makhluk hidup lainnya. Dukuh Grogol seperti yang dijelaskan pada sub-bab sebelumnya memiliki dukungan modal lingkungan yang dapat dimanfaatkan sebagai potensi wisata. Potensi alam yang miliki oleh Dukuh Grogol seperti: Bukit yang biasa dinamai Gunung Pincuk oleh masyarakat local, persawahan, sungai yang jernih, dan 
lingkungan budaya. Modal lingkungan yang dimiliki oleh Komunitas Desa Wisata Grogol ini dapat dijadikan atraksi wisataseperti bukit atau Gunung Pincuk dijadian wisata tracking atau jelajah, Persawahan untuk wisata pertanian, dan sungai dijadikan komunitas untuk paketan wisata river tubing. Sementara itu untuk modal lingkungan yang berupa lingkungan budaya di Dukuh Grogol sudah berdiri beberapa sanggarsanggar seni seperti: seni pedalangan, seni tari dan karawitan.

d. Modal Teknologi Keberadaan teknologi, adalah salah satu unsur dari tujuh universal kebudayaan menurut Koentjaraningrat (2009). Modal teknologi ini tidak hanya mengenai alat-alat modern yang canggih. Tetapi juga mengenai perlatan yang menunjang kehidupan manusia, dalam konteks ini adalah komunitas desa wisata. Modal teknologi yang dimiliki oleh komunitas ini seperti: Handy Talky (HT) untuk kordinasi pada saat acara, speaker atau pengeras suara, website dan sosial media untuk publikasi dan marketing dan sebagainya. Keberadaan teknologi ini untuk mempermudah jalanya komunitas.

e. Modal Manusia Sumber daya manusia, merupakan modal utama dalam berkomunitas. Kulaitas sumberdaya manusia akan sejalan dengan kualitas komunitas. Pada kasus desa wisata Grogol sumber daya manusia secara kuantitatif pada awalnya tahun 2010 hanya berjumlah 5 orang, tetapi pada akhir 2015 berjumlah 50 orang dan meningkat setiap tahunnya. Pemimpin komunitas Desa Wisata Grogol adalah seorang PNS di Dinas Pariwisata Kabupaten Sleman dengan relasi dan pengalamannya dapat mengembangkan komunitasnya. Untuk meningkatkan kualitas SDM pengelola khususnya yang bertugas memandu wisatawan mereka belajar dengan cara melihat dan belajar dari pemandu outbond profesional seperti komunitas Lombok abang dan Tosca. Selain itu juga pengelola Desa Wisata Grogol diajak studi banding ke desa wisata yang jauh lebih berkembang seperti Pentingsari, Hal ini dilakukan supaya mereka bisa belajar dan membandingkan bagaimana cara memandu wisatawan.

f. Modal Sosial Modal sosial adalah norma dan aturan yang mengikat warga masyarakat yang berada di dalamnya, dan mengatur pola perilaku warga, juga unsur kepercayaan (trust), dan jaringan (network) antar warga masyarakat atau kelompok masyarakat. Norma dan aturan yang ada juga mengatur perilaku individu baik dalam perilaku ke dalam (internal kelompok) maupun perilaku ke luar 
(eksternal). Para anggota Komunitas Desa Wisata Grogol juga mengikuti aturanaturan sertai nilai-nilai yang disepakati oleh komunitas. Aturan aturan ini lebih banyak berupa aturan yang tidak tertulis seperti berngkat bersama pulng bersama ketika menyambut wisatawan khususnya wisatawan yang kolektif. Selalin norma sebagai anggota komunitas desa wisata para anggota juga terikat norma sebagai warga Padukuhan Grogol.

\section{Diskusi: Strategi Kapasitas Komunitas Desa Wisata Grogol}

Kapasitas komunitas pada dasarnya selalu dinamis, dapat berubah sejalan dengan perubahan sosial dan budaya yang menyertai komunitas. Ragam jenis perubahan kapasitas komunitas tergantung sejauh mana difusi dan inovasi yang berlangsung pada komunitas. Perubahandalam hal kapasitas komunitas, apakah perubahan yang direncakan dan dikehendaki atau perubahan itu yang beralngsung tanpa direncakan. Setiap komunitas pasti memliki social agent, dan agen yang menghendaki perubahan dinamakan sebagai agent of change. Kapasitas dan perubahan ini dijalankan dalam sebuah komunitas dalam rangka untuk mencapai tujuan yang diharapkan.

Tujuan yang diharapkan bersama dalam sebuah komunitas ini tidak lepas dari kapasitas dari komunitas. Pengembangan kapasitas komunitas dimulai dari memhami karakter dan modal komunitas seperti yang sudah digambarkan pada sub bab pembahasan sebelumnya. Apa saja yang mejadi pengaruh dan bisa mempengaruhi dalam proses transformasi komunitas harus juga diperhatikan. Selanjutnya strategi dan fungsi untuk mencapai tujuan komunitas menjadi penting selain tentunya agenagen sosial yang ada dan mempengaruhi jalannya komunitas. Berikut gambaran kerangka kerja rasional yang menggambarkan pengembangan kapasitas komunitas menurut Chaskin (2001): 
Gambar I. Kerangka Kerja Rasional:

Komunitas dan Pengembangan Kapasitas

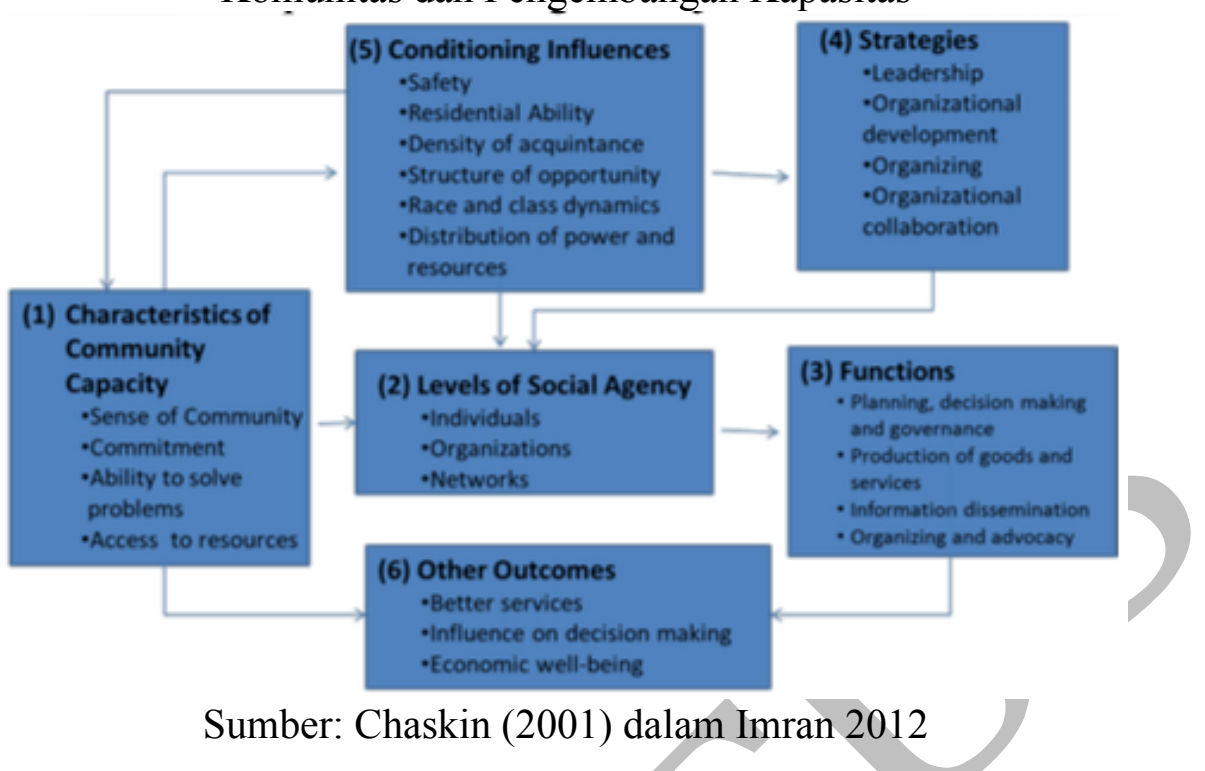

Agen sosial (social agent) menjadi satu titik penting dalam pengembangan maupun perubahan suatu komunitas. Agen sosial ini berperan menetapkan bagaimana strategi tindakan sosial dapat terlibat dan membantu pihak yang tertarik pada pembangunan kapasitas komunitas untuk berpikir lebih efektif tentang kapasitas dalam pekerjaan dan komunitas mereka sendiri. Belajar dari kasus Komunitas Desa Wisata Grogol yang sempat vakum pada tahun 2001-2010, dan kembali eksis pada tahun 2010. Mulai lahirnya kembali komunitas desa wisata ini tidak terlepas dari adanya agen sosial yang mampu menggerakan anggota untuk bergabung, membangun jaringan dengan dinas terkait membangun jaringan marketing dan sebagainya. Sehingga pasca dilahirnya kembali pada tahun 2010 komunitas ini tumbuh dan berkembang secara perlahan.

Berdasarkan hasil penelitian di Komunitas Desa Wisat Grogol diperoleh gambaran empiric bahwa agen sosial menempati peranan penting dalam proses peningkatan kapasitas komunitas. Selain itu strategi dari komunitas menjadi tujuan dari inisiatif komunitas atau melaksanakan kapasitas mereka mencapai tujuan tertentu. Di dalam komunitas yang bekerja dengan baik, kapasitas komunitas relatif diperkuat oleh adanya interaksi terus- menerus di antara tiga dimensi yang mendasar. Berikut strategi pengembangan kapasitas komunitas dari empat strategi utama, yaitu 
(Chaskin, 2001):

a. Leadership Development, hal ini terkait dengan pada pengembangan jiwa kepemimpinan, keahlian baik teknis maupun non-teknis, komitment, keterlibatan, dan keefektivan individu dalam proses pengembangan komunitas. Hal ini biasanya dilakukan oleh Komunitas Desa Wisata Grogol dengan memberikan kesempatan para anggotanya untuk memandu para wisatawan atau memberikan kesempatan untuk memimpin para anggota yang lain secara bergantan pada tiap acara di komunitas.

b. Organizational Development, hal ini termasuk membentuk organisasi baru atau memperkuat yang sudah ada sehingga mereka dapat bekerja lebih baik atau mengambil peran baru. Penguatan organiasai yang suah ada misalnya dengan upgrading yang dilakukan oleh Komunitas misalnya dengan wisata bersama ke obyek-obyek wisata di Gunungkidul, melakukan studi banding ke desa wisata yang duah maju dan pertemuan rutin tiap bulannya di rumah anggota komunitas.

c. Community Organizing, memiliki target pengumpulan aspek-aspek dari fungsi komunitas dan memobilisasi stakeholder individu untuk menjadi kolektif pada akhirnya. Pada Komunitas Desa Wisata Grogol dalam mengembangankan organisasi berinovasi membentuk sub-oraganisasi yang bermuara pada Komunitas Desa Wisata Grogol, misalnya sub organiasasi ibu-ibu yang menyediakan makan bagi para wisatawan.

d. Interorganizational Collaboration, yakni dengan membangun infrastruktur organisasi komunitas meliputi pengembangan hubungan dan kerjasama kolaboratif dalam level organisasi. Misalnya bekerjasama dengan travel agen atau pemandu wisata professional. Dengan kerjasama itu Komunitas Desa Wisata Grogol selain mendapatkan tamu atau wisatawan juga memperoleh ilmu bagaimana cara memandu wisatawan.

\section{KESIMPULAN}

Pengembangan pariwisata pedesaan yang berbasiskan pada komunitas local dalam bentuk desa wisata ini disalah satu sisi adalah kebijakan pemerintah daerah untuk memberdayakan masyarakat local yang bersifat top down. Tetapi disisi lain ada desa wisata-desa wisata yang bermunculan dari hasil inovasi masyarakat local, mereka berkomunitas dan memulai mengembangkan pariwisata di tempat diamana 
mereka tinggal. Seperti halnya Dukuh Grogol sudah dimulai sejak dari tahun 2001 dan pada perjalanannya vakum selama sepuluh tahun. Hal ini dikarenakan proses adobsi budaya menerima "penolakan (rejection)" dan kesadaran anggota komunitas berkomunitas masih sangat lemah. Selain Desa Wisata Grogol banyak kasus yang dialami oleh desa wisata yang lain di Kabupaten Sleman yang sulit berkembang dan mati, karena hanya dilahirkan oleh pemerintah kemudian kuran sustainable dalam memeliharanya.

Setelah sepuluh tahun vakum "desa wisata" ini kemudian kembali di bangkitkan kembali di tahun 2010, yang diinisiasi oleh kaum muda. Meskipun dalam proses komunikasi difusi atau dalam bahasa Rogers disebut "Innovation-Discision Process" kembali menerima penolakan, tetapi dengan potensi dan kekuatan seadanya konsep "desa wisata" dapat berjalan dan berkembang di Dukuh Grogol seperti sekarang. Hal ini bisa dilihat bagaimana perbedaan antara tahun 2001 (awal terbentuknya) dan 2010 (pembentukan ulang). Pada tahun 2001 pengembangan pariwisata pedesaan bersifat top down dan akhirnya sulit berkembang dan pada tahun 2010 dilahirkan kembali dengan inovasi dari agen of change dalam komunitas, dan akhirnya berkembang seperti sekarang.

Dalam rangka mengembangkan pariwisata pedesaan berbasis komunitas perlu adanya peningkatan kapasitas komunitas. Pengembangan kapasitas komunitas sangatlah kompleks, dimana banyak unsu-unsur yang perlu diperhatikan. Modal komunitas menjadi unsur-unsur kapasitas komunitas yang dapat ditingkatkan. Modal komunitas antara lain: modal fisik, modal financial, modal lingkungan, modal sumberdaya manusia, modal sosial dan modal keberadaan teknologi. Selain modal pengembangan juga harus dimotori oleh agen sosial sebagai agen of change (agen perubahan), dan bebagai macam strategi komunitas. Staregi komunitas menurut Chaskin (2001) ada empat stategi utama yaitu: leadership development, organizational development, community organizing dan interorganizational collaboration. Kesemua strategi ini dikembangkan dalam rangka meningkatkan kapastias termasuk dalam konteks penelitian ini adalah kapasitas Komunitas Desa Wisata Grogol. 


\section{DAFTAR PUSTAKA}

Ahimsa Putra, Heddy Shri (dkk). (2003). Ekonomi Moral, Rasional dan Politik : Eseiesai Antropologi Ekonomi. Yogyakarta: Kepel Press

, Heddy Shri. (2011). Pariwisata di Desa dan Respon Ekonomi: Kasus Desa Brayut di Sleman, Yogyakarta. Patrawidya 12 (4): 635-659.

, Heddy Shri. (2014). Pariwisata dan Perubahan Kebudayaan : Desa Wisata Sebagai Arena Akulturasi Budaya. Proposal penelitian: Tidak diterbitkan

Arni, A.G.,Khairil,W.A.,Abdullah,M. \& Zaiton,S. (2015). Attributes of Successful Public Participation in Planning for Sustainable Tourism in Protected Areas: A Modified Delphi Study. Pertanika J. Soc. Sci. \& Hum. 23 (S): $49-64$

Bintarto. (1983). Interaksi Desa-Kota. Yogyakarta: Ghalia Indonesia

Chaskin, Robert J., et al. (2001). Building Community Capacity. New York: Walter de Gruyter Inc.

Cohen, Eric. (1984). The Sociology of Tourism: Approaches, Issues, and Findings. Annual Review of Sociology, Vol. 10 (1984), pp. 373-392

Cohen, J.H. (2004). Textile, Tourism and Commmunity Development. Annals of Research, Vol. 28, Isue 2. Halaman 387-398

Demartoro, Argyo. (2015). Pemberdayaan Perempuan dalam Pariwisata Berbasis Komunitas. Surakarta UNS Press

Denzin, Norman K \& Lincoln. (2011). Handbook of Qualitative Research. Terj. Yogyakarta, Pustaka Pelajar

Ember, C.R \& Malvin, E. (1984). Cultural Anthropology. New York: Printice-Hall

Hampton, Mark P. (2003). Entry Points for Local Tourism in Developing Countries: Evidence from Yogyakarta, Indonesia. GeografiskaAnnaler. Series B, Human Geography, Vol. 85, No. 2 (2003), pp. 85-101

Ho, Puay-Peng, (2000). Preservation Versus Profit: Recent Development in Village Tourism in China. Traditional Dwellings and Settlements Review, Vol. 12, No. 1, The end of Tradition? Seventh International Conference October 12-15, 2000 Trani, Italy (Fall 2000), pp 60-61

Hussey, Antonia Hussey. (1989). Tourism in a Balinese Village. Geographical Review, Vol. 79, No. 3 (Jul, 1989), pp. 311-325 
Imran, Andelissa Nur. (2012). Identifikasi Kapasitas Komunitas Lokal dalam Pemanfaatan Potensi Ekowisata bagi Pengembangan Ekowisata di Kawah Cibuni. Jurnal Perencanaan Wilayah dan Kota Vol 23/No.2 Agustus 2012

Jamal, T. B., \& Getz, D. (1995). Collaboration theory and community tourism planning. Annals of Tourism Research, 22(1), 186-204.

Koentjaraningrat. (1994). Kebudayaan Jawa. Jakarta: Balai Pustaka

(2009). Pengantar Ilmu Antropologi.Jakarta: Penerbit Rineka Cipta

Muriawan,P.A,. (2006). Konsep Desa Wisata. Jurnal Manajemen Pariwisata, Juni 2006, Volume 5, Nomor 1

Nash, Dennison, Anne V. Akeroyd, (ed.al). 1981. Tourism as an Anthropological Subject (Comments and Reply). Current Anthropology, Vol. 22, No. 5 , pp. 461-481

Nunkoo, Robin. (2011). Developing a community support model for tourism. Annals of Tourism Research. Volume 38, Issue 3, July 2011, Pages 964-988. https://doi.org/10.1016/j.annals.2011.01.017

Pitana, I.G. \& Putu, G. (2005). Sosiologi Pariwisata. Yogyakarta: Andi

Pendit, Nyoman S. (1990). lmu Pariwisata "Sebuah Pengantar Perdana. Jakarta: PT. Pradana Paramita

Rogers. Everett M. (1983). Diffusion of Innovations (Third Edition). New York. The Free Press

Storonza, Amanda. (2001). Anthropology of Tourism: Forging New Ground for Ecotourism and Other Alternatives. Annual Review of Anthropology, Vol. 30,pp. 261-283

Salazar, Noel B. (2011). Community-based cultural tourism: issues, threats and opportunities. Journal of Sustainable Tourism. Volume 20,2012- Issue 1: 20 th Anniversary Issue. http://dx.doi.org/10.1080/09669582.2011.596279

Sebele. Lesego, S. (2010). Community-based tourism ventures, benefits and challenges: Khama Rhino Sanctuary Trust, Central District, Botswana. Tourism Management. Volume 31, Issue 1, February 2010, Pages 136-146. https://doi.org/10.1016/j.tourman.2009.01.005

Wang, Hui, .ZhaopingYang, LiChen, JingjingYang, dan Ruili. (2010). Minority community participation in tourism: A case of Kanas Tuva villages in Xinjiang, China. Tourism Management. Volume 31, Issue 6, December 2010, Pages 759-764. https://doi.org/10.1016/j.tourman.2009.08.002 